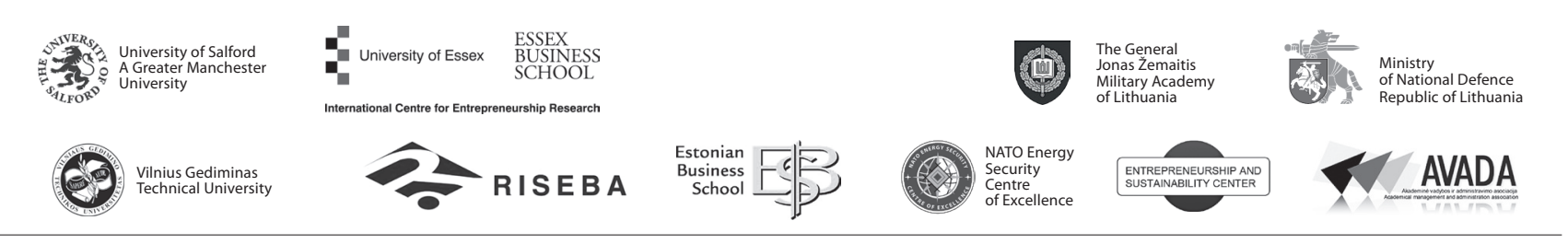

\author{
JOURNAL OF SECURITY AND SUSTAINABILITY ISSUES \\ ISSN 2029-7017 print/ISSN 2029-7025 online \\ 2017 December Volume 7 Number 2 \\ http://doi.org/10.9770/jssi.2017.7.2(3)
}

\title{
TOWARDS SAFETY OF SOCIETY: RETHINKING PRINCIPLES OF POLICE FINANCING
}

\author{
Gintautas Danišauskas \\ Mykolas Romeris University, Ateities Str. 20, LT-08303 Vilnius, Lithuania \\ E-mails:danigint@mruni.eu
}

Received 23 February; accepted 15 September 2017

\begin{abstract}
Section 2 of the Constitution of the Republic of Lithuania establishes the basic human of our society security rights. In accordance with the basic law of our state human has a right to life, health, freedom, personal integrity, property and other rights. The law enforcement agencies of the Republic of Lithuania, including the police play a major role in realizing these rights in protecting these human values. From which responsibility for performing duties in many cases belongs to the quality of the protection of the said constitutional values in our society and the comfortable, easy staying in Lithuania of each person. However, how to find the optimal model of the relationship between the society and the police, so that each side - the public and its institution, the police would be interested in legal relations - the society should encourage its authority to carry out safety functions, responsibly and willingly, and the police has to ensure proper human security. In this article, possible model of legal services between police and society based on free market (supply and demand) principles is analyzed. Based on free market principles and pairing its elements - supply and demand with law elements - duty and right. Upholding the idea, that free market is an optimal and the most rightful way of cultural exchange, theoretically attempting to model legal relations in free market principles to achieve the most rightful exchange of legal services between society and police, while at the same time meeting security needs of society.
\end{abstract}

Keywords: free market principles, safety, legal service, police activity, social relations, legislation

Reference to this paper should be made as follows: Danišauskas, G. 2017. Towards safety of society: rethinking principles of police financing, Journal of Security and Sustainability Issues 7(2): 203-210. https://doi.org/10.9770/jssi.2017.7.2(3)

JEL Classifications: Q3

\section{Introduction}

Safety and security are issues of contemporary concern (e.g. Holcner, Olejníček, 2017; Genys, Krikštolaitis, 2017; Tumalavičius, Greičius, 2017; Trofimovs, Ivančiks, 2017). Thsese issues are multi-faceted therefore embrace various topics, belonging e.g. to economical relationships field or to human rights field. If we considered those mebtioned fields further, we would find so many analogies between economics and law based relationships, as well we would notice similarities between them. This article will review similarities between free market principles and law in its authentic meaning: when law becomes rightful in protection of human rights, and on the free market basis can develop into non exploitative relationship between authorities (in this case police) and society, which without a doubt would contribute to meeting security needs of society itself. Such relationship could be described as exchange of legal (equivalent) services. Considering free market princip of supply and demand in human relations as the only rightful, because both sides: selling services and receiving them has a free choice to set prices by the consumer's intention to buy them. The prices are adjusted by increase or decrease of such demand. Both sides and the society itself win from this type of relationship when receiving relevant police services. According to A. Krivinš, police should be understood as service provider. This institution can be defined as of high importance in protecting human rights, because as its duty it protects people 
from criminal attempts at life, health, other human rights and freedoms, asset integrity and interests of society or state. Such police work requires considerable resources (Krivinšs, 2015). And it is realized that the state is not always capable of ensuring them. So it is necessary to find more rational and fairest ways of police funding in the way of changing funding principles while expecting appropriate police services in return. In 2015-2016 public opinion polls, carried out by Lithuanian Ministry of internal affairs analysis shows that very small percentage of people who trust police activity. Loss of trust in country's institution is not unique phenomenon in less developed counties (Petrenko et al., 2017; Fabuš, 2017). While, for example in Finland 86\% of citizens trust police (Police of Finland 2 2017) Therefore it is necessary for society to look for other ways to promote police service relationships. Establishing rightful law, its structural elements have to be balanced respectively, as they are balanced in free economy. Identical to free economy which is based on supply and demand, the contents of law are also based on two elements: right and duty. In this article we will attempt to answer the question of how to set these items balance and imbalance in the public and police relations. Since we live in democratic society, in which all areas of life administrative - team relationship between supply and demand changes in the form of the free market, so that is why we should not reject security field principles of social security sphere.

Problem. Valid legislation that regulates relationship between police and society are not sufficient enough for society's expectations in practice. More duties are requested from police by society, while funding for these additional services is insufficient, making police unmotivated and its services ineffective. So far the activity of these subjects was research more formally, that is, stating police rights and duties itself, without linking them to humanistic content, or discussing if performing these additional duties really contributes to effective protection and realization of citizen rights.

The research objective. An attempt to introduce the maximum acceptable relations between the police and the public, which are based on non-operational alignment, paved on free market principles, showing that the application analog of free-market principles can be effective not only in the private sector but also in the public service. The emergence of such relations will be analyzed in accordance with the vision of a free market - supply and demand principles between the public and the police authorities.

Further research. This article is author's and other researchers continuous study for finding the most acceptable way to adjust the public and police relations between adequate services. However, the author has not encoounteres other researches where possible police and society legal relations are analyzed through free market economy principle lences.

\section{The reciprocal exchange at equivalent services - the promoting factor in their economic equivalence and justice}

The $5^{\text {th }}$ article of constitution of Republic of Lithuania obliges state institutions to "serve citizens" (The Constitution of The Republic of Lithuania, 1992). Police, as governmental institution must serve in ensuring safety of people in a field of solving and preventing illegal activities. According to Director of National Institute of Justice U.S. Department B, Charles and Management J. Kennedy from Harvard University, police must not only react when crimes are made, but should also be the subject that prevents the emergence of negative influence to security conditions (Charles, 2013), implying, that police should operate preventively, especially towards maintaining protection of human rights. In democracy, this constitutional obligation has to be understood as cultural equality of subjects. So that any reciprocal services between subjects must be without any possibility of exploitation. These possibilities are eliminated by free market. Therefore, maintaining the equality of sides, the exchange of services must be on equivalency basis. This provision saves society from being enslaved by government authorities and vice versa. This type of service becomes free from exploitation, as it is based on exchanging services on the basis of equivalence. Institutions that do not participate in exchange of services, in terms of a democratic constitution, are illegally operating. Specifications of this Constitution article require state institutions to treat the duties performed as some sort of form of public services so the service providers public servants have the right to receive services form society in return on the basis of public officials to comply with their rights. It is imperative that requires an investigation of the activities of state institutions not only in 
form but also in content (mutual services) point of view.

On the other hand, it would be wrong to say that police funding is short. In 2016 the budgetary allocations to the police were 209,5 million Euro, (A review of police activities, 2016) while trust in the police is really low. There were registered 25000 events for 100 thousand inhabitants annually in the Police register (one for every for country's population) (A review of police activities, 2016). This means, that it is necessary to look for acceptable economic relations with police and first of all for new forms of funding to ensure it's willingness to service the society. Sean from Massachusetts Institute of Technology says that protection from criminal activities is highly related to economical relations (Sean, 2000). It is unavoidable to reach economical relations in terms of legal services.

Lithuanian scholarly works have been written about the legal services of their authentic conception. Legal (economically based, corresponding to the supply and demand principles) service is understood as one user's adequate legal responsibilities for the performance of another's given equivalent options (rights), what basically meets free market - the supply and demand principles. If reciprocal relationship is considered the size of $100 \%$, which together consists of the rights and duties, then legal service occurs when one subject gives to another $50 \%$ of the possibilities, while the other for fulfills $50 \%$ of the duties. In economics we know that the best, the highest quality result in cultural exchanges, in producing goods or services is achieved when guided by market forces - supply and demand principles. The market, in which each economic member obeys price, is known as competitive (Varian, Hal, 2003). Blackstone and Hakim state, that competition brings huge benefit encouraging efficient police work (Blackstone, Hakim, 2016). In terms of competition, winner is the one who had offered better quality goods or services. This is also relevant in competition between security services provided by private and state institutions. Professor Brian in his topic about relations between USA police and private security structures highlights that 30 years ago the number of police officers was bigger than private security staff, but now the tables have turned and private security guards outnumber police officers tree times (Brian, 2000). This shows us how free market principles dominate over governmental institutions. Professor also discuses the direction of police privatization issue (Brian, 2000), eve though he states that police is an institution exclusively from public sector (Brian, 2000). This is servicing all the people in need despite their financial state. For example, people with bad personal financial situation could not afford security service from private providers (Blackstone, Hakim, 2016). That is why it is relevant, for example, in Lithuania to have governmental police promoted to operate parallel towards market principals. Even though it is understood, that these origins are more focused on the private, but not on the public sector. In contrast to the state owned, each commercial structure chooses itself materially useful activity and service providers. If, let's say, in our country, private profit-making police would be legalized, its goal would be to maximize profits from its cultural activities. Primary interest of this service would be to choose the most relevant disclosure of the crime area to particular person, as soon as possible to solve a crime committed against him. In fact, the victim would be willing to pay maybe the last penny (or even borrowed money) it has, in order to get the crime solved as soon as possible. Also the private police would choose wealthy victims over the poor, with the aim of high profits. Still, conditions of our social order place police as governmental institution and according to $5^{\text {th }}$ article in the Constitution of Republic of Lithuania, this institution is unable to choose neither its clients nor particular easier for itself and profitable field of activity. Police is obliged by legislation to carry out specific role. This service includes all the society as public authority, obliged to defend each and every taxpayer's rights. Police with the status of state institution services can't be bought by single member of society. Police is an institution of state, its services are bought via government. Every member of society as direct police service user pays taxes to the government. So the government becomes police service buyer in the economic way. On the other hand, market is always involved with direct state interference (Strange, 1998). Every government has an opportunity to distribute goods - profit (taxes), to distribute special rights and duties or material form even in the private sector. While market, is based and influenced by price mechanism and go with supply and demand (Strange, 1998). Therefore, the mutual exchange of service content and their equivalents between the subjects also depend on these factors. For example, activities and functions of any private institution can be adjusted depending to state demands. However, the more adjustments are made, the less market and legal services are left. It is understood that a competitive market for citizens' when dealings with public authorities has low possibilities, because the 
state government owns a monopoly and there is no possibility for competition. Science of economics states, that in terms of pure monopoly, prices are decided by the monopolist (Urbonas et al, 2009). But in the law based service providing relations, citizen, who is seeking career as civil servant, can become an object of competitive exchange. Such a person becomes a subject of the supply and demand factors of entrenchment in the public service. In this case, to execute important state functions, funding and other social values, adequate expected social benefits, are allocated. Therefore, civil servants, who can perform duties adequate to salary, may be selected through competition. Naturally, that interchange of cultural exchange process itself is most acceptable when it is regulated by money as equivalence and measure of justice. Person is affected by these processes, he is motivated to work, to improve, to develop himself as personality (Martinkus, Žilinskas, 2008). Therefore equivalent or equal exchange of services between legal entities, can lead to a fair, non-exploitive mutual services even between the governmental institutions and citizens.

\section{Free market principles as factors to rise an oportunity for legal services between society and police}

First of all, question must be answered before talking about establishing legal services between society and police: how to measure the size of police and society service economic interest imbalance. It is understood that there is no, and it cannot be, any direct mathematical answer in reciprocal service relationship. As we live in democratic society, where in all areas of life administrative-team relations are changed to supply and demand form by free market. These principles should not be rejected when taking care of social security matters as well. According to them, we can say that if the police or society itself in one of its cultural activities is trying to avoid the mutual commitments, which means that for a specific legal entity, this is not useful, because the obligation is not secured by adequate feedback in the form of an economic form. Because according to economic theory, each person is considering what kind of work to choose, how much and why he is paid for it, what determines the price of goods or services, how this does implicate subject's living standards, and so on (Martinkus, Žilinskas, 2008). And also it is important for everyone not only what to expect today, but what to expect in the future too (Blanchard, 2006). If society's economic opportunities are limited, of course, that in accordance with economic theory, it decides how to increase the resources available to meet the needs of basic services (Čiegis, 2012). Thus, in proportion to the absence of sufficient motivation and desire to exchange equivalent of mutual exchange, the market (efficiency) stimulating factors does not work. The one of most important factors is meeting certain needs of the subject in a form of benefits. However, both the public and its individual member, has many needs and those needs cannot be equally treated, it is necessary to distinguish them according to priorities like: the most important, less important and non-valuable. In economics, such needs are known as not necessarily upheld, and in the scale of the needs first of all are those without which it is impossible to survive (Snieška, 1999). They can be measured in usefulness. Usefulness is understood as satisfaction offered by consumption of service (Snieška, 1999), and the usefulness of the service becomes relevant entity of cultural values in the selection criteria. As for the performance of the police service and the need for it, it is important to highlight that these services are very important for each member and society as a whole, because without them the civilized communication could hardly be possible. In addition, people would constantly feel the spiritual discomfort without being maximum safe, especially from the violence. Security from violence may be more important than the safety from disease, disability, or other coincidences (Strange, 1998). Unsafe social life in a war against all and would bring much suffering to every member of the society, so the job of the police remains a priority and in top of the scale.

Economic science says that the utility of services depends on the quantity of services consumed (Snieška, 1999), but this is valid to the real (tangible) services performed. In social relations, as well as in the police activity it may occur alleged, quasi performed services that are not useful at all, or their efficiency is very low. Society assigned a set of various duties for the police institution, which are not performed properly because of police's excessive workload. These alleged services are carried out and captured in reports wasting time and effort. As the real police work is not done, employees of these institutions are interested to cover it with the veil of mystery. In a such mysterious activity appears "the alleged service" capability, which is a matter of public distrust and deterioration of public and police relations. In addition, police officers while being fatigued and strain in often formal, insignificant activities, become harsh, insensitive, and unable to show the necessary at- 
tention to people. Therefore, the efficiency of such police services is very low. To meet its security needs, society enables regulations, inadequately trying to oblige the police to make more new functions and to fill activity reports. This leads to new forms of police activity evasion when services remain unallocated, and the preferred public needs of security unsatisfied.

The experience of democratic world shows that market, guided by demand and supply principle leads to a healthy economy, because, as already mentioned, these principles should not be dismissed in the public and police services exchange process. Time has shown that the police activities promoting administrative - team approach did not give the expected results. It is necessary to find other fair cultural exchange process promoting factors, which contribute to enhancing welfare of police officers, which is the base of law enforcement activities which meet society expectations.

Economic science claims that increasing the use of the same services to the extent, needs are gradually fulfilled (Snieška, 1999). If police operational function as the most important for human rights - prevention of offenses, would be given sufficient demand and supply based on the material focus, the public security needs would come closer to their desired satisfaction level until reaching the maximum. In economics, this is called the principle of equilibrium, where prices vary until the quantity demanded by people, becomes equal to the proposed so the supply and demand become equal. Later, every next material support to the police would provide the growing supply of society's security needs, as the preventive activity every single time would have achieved a higher level, so keeping present security status would cost much less. This work would require a smaller number of police officers, as the maximum preventive work in efficiency (market) conditions would be accomplished. Further amount of police services must be regulated by effectiveness principles itself. Greater material resources are allocated in case of larger public security preferences, and if these preferences decrease - funding would decrease also. Taxpayer's needs would be the maximum satisfied with police service as a result of efficiency (market) demand and supply method. On the other hand, duties performed freely and without obligatory commitments, would become useful and necessary to police officers themselves. The effective (market) mechanism would lead to mutually beneficial cultural exchanges, e.g. legal police and public services, but how to determine the usefulness of police activity in comparison with other public needs? Economic science claims that the term "utility" means satisfaction which consumer receives service consumption. So far there have been many attempts to "measure" this satisfaction, but still the measure could not be found (Snieška, 1999). Each benefit offered is assessed subjectively in a priority scale of a separate subject. In terms of determining public values in the scale of priorities, it should be highlighted that the real situation may not always be reflected when state institutions initiate and implement laws and other regulations, because of the gap between the everyday life of ordinary citizens so these public authorities not always are able to assess the real priorities of values. In the evening or at night, ordinary residents of the Republic of Lithuania often return home - daytime left unprotected dwellings, automobiles left in unprotected sites, etc.

While government is initiating and participating in legislation, implementing regulations, is much less likely to face such problems, therefore has no such initiative, and may not always be interested to see the actual security situation. Science of psychology studies significance of stimulus to particular human behavior (Justickis, Navikas, 1995). As mentioned above, the operating efficiency (market) principles would gradually decrease police services in certain areas of activity when the needs of the population are maximally satisfied. This would reduce the public capital investment in a specific area of the police, and the service would fall in price. It was found that the fall in service prices encourages consumers to buy more of them (Snieška, 1999). This would let to carry out less significant to the society police service feature at the same cost. This performance (market) process would lead society to the maximum security options for its members. If, say, there is a potential threat of dangerous crimes, of course, the police would focus on preventing them, and would have less potential for minor offense prevention. The removal of dangerous criminal threats as far as possible, police could focus on preventing not such dangerous crimes. This means an increase of public security and human rights protection. However, the question is how to assess individually perceived values. For one person theft of 100 euros may be much important and dangerous then 1000 euros theft to another. How should police, providing services and satisfying public needs, act? To which of the victims police should devote priority and efforts to find the thief? In 
many of these relationships determination of value priorities are regulated by rule of law. For example in $108^{\text {th }}$ article of ANK (Code of Administrative Offences) of Republic of Lithuania, petty theft is, if the value of the stolen property does not exceed three MSL (minimum subsistence level), and if the value of property is greater than this measure, a criminal case must be brought in, and of course, this type of offence should be a priority (Code of Administrative Offences, 2015). So again, it remains a relative problem of law and justice. However, if the values are evaluated subjectively, a common approach to their value has to be subjective too, so there is no other way than to set values and priorities the whole society-wide and in accordance to them, police as the state authority, must carry out its functions.

The police are a consequence of the whole society, its institution, that's why police activities must follow the whole society's established customary law and moral norms which are largely contained in the Constitution of the Republic of Lithuania and other laws. Therefore, if all members of society are equal to the social norms and laws, each of them realizes that the person - a man or a woman, an intellectual or a worker - life is more valuable than other body injury of other person, robbery is more dangerous than ordinary theft and even a small crime is more dangerous than an administrative offense. Police acting on behalf of the law enacted by the public's elected representatives, must follow the hierarchy of values and on the basis of normative acts to provide services to the public.

\section{Conclusion}

1. Free market, acting on the grounds of supply and demand, influences the law based services between the subjects to emerge and expand. It creates conditions to use public goods rationally.

2. Since the best cultural performance is achieved trough free market principles of supply and demand, these principles should not be withdrawed when seeking fair exchange in the public and police relations.

3. Is there an imbalance of duties and rights in the cultural relations between the society and the police and what scale it is? There is no direct mathematical answer to this question and it can not be found in social relations. However, criteria under which content of law balance or imbalance may be determined should be found. These criteria should be efficiency (market) and understanding that each duty can be fully satisfied only if it becomes desirable and useful to the relevant legal subject. And if the subject does not fully fulfill the duties or is trying to avoid them completely, that means that it has no interest, and the other legal relationship party is to blame for as it withholds these obligations with relevant economic values. Thus can determine which relationship side is responsible for the legal service content imbalance.

4. Adding state owned police to effective (free market based) relationship with society, would lead to both: balance between rights and duties, law based reciprocal services between society and police institution.

\section{References}

2015 m. policijos veiklos apžvalga. 2016. [A review of police activities]. Available in Internet: http://www.policija.lt/index.php?id=2875 Autorių kolektyvas. Teisès teorijos įvadas. [Theory of law].

Blackstone, A. Hakim, S. 1996. Police Services: The Private Challenge. Independent Institute. Available in Internet: http://www.independent.org/publications/policy_reports/detail.asp?id=10\#5

Blanchard, O. 2006. Macroeconomics.

Brian F. 2000. The Privatization and Civilianization of Policing, Volume 2. https://www.ncjrs.gov/criminal_justice2000/vol_2/02c2.pdf

Charles P. 2013. Nemath, Private Security and the Law, 640 p. https://www.elsevier.com/books/private-security-and-the-law/nemeth/978-0-12-386922-7

Charles, B. 1993. Community Policing and the Police Officer. No. 15. https://www.ncjrs.gov/pdffiles1/nij/139164.pdf 
Čiegis, R. 2012. Makroekonomika. [Macroeconomics].

Fabuš, M. 2017. Current development of business environment in Slovakia and Czech Republic, Entrepreneurship and Sustainability Issues Vol.5 No1, pp. 127-137. https://doi.org/10.9770/jesi.2017.5.1(10)

Genys, D.; Krikštolaitis, R. 2017. The public perception of nuclear energy in Lithuania, Journal of Security and Sustainability Issues Vol. 7 No1, pp. 17-25. https://doi.org/10.9770/jssi.2017.7.1(2)

Hakim, S.; Gaffney, M.A. 1994. “The Structure of the Installers Market,” Locksmith Ledger.

Hart, H. L. A. 1997. Teisès samprata. [The concept of law].

Holcner, V.; Olejníček, A. 2017. Possibilities of defense spending stabilization, Journal of Security and Sustainability Issues Vol. 7 No1, pp. 5-15. https://doi.org/10.9770/jssi.2017.7.1(1)

Justickis, V.; Navikas, G. 1995. Bendravimo psichologija. [Psichology of communication].

Kriviņš, A. 2015. Towards security and safety: Police efficiency across european countries, Journal of security and sustainability issues Vol. 5, No1, pp. 35-44. https://doi.org/10.9770/jssi.2015.5.1(3)

Lietuvos Respublikos administracinių nusižengimų kodeksas. [The Code of Administrative Offences] Register of legal acts.. 2015, Nr. 0.

Lietuvos Respublikos Konstitucija. [The Constitution of the Republic of Lithuania]. 1992, Nr. 33-1014.

Lietuvos Respublikos policijos veiklos įstatymas. [The law of police activities] Register of legal acts. 2015, Nr.0.

Mahoney J. 2000. Path Dependence in Historical Sociology. Theory and Society, Volume 29.

Maldeikienė, A.; Rekutè, G. 2007. Makroekonomika. [Macroeconomics]

Martinkus, B.; Žilinskas, V. 2008. Ekonomikos pagrindai. [The basement of economics].

Petrenko, E.; Iskakov, N.; Metsyk, O.; Khassanova, T. 2017. Ecosystem of entrepreneurship: risks related to loss of trust in stability of economic environment in Kazakhstan. Entrepreneurship and Sustainability Issues Vol 5, No1, pp. 105-115. https://doi.org/10.9770/ jesi.2017.5.1(8)

Police of Finland. 2017. Available in Internet: https://www.poliisi.fi/en

Sean, M. May. 2000. The Economics of Crime and Econometric Methodology. http://research.upjohn.org/dissertation_awards/29/

Snieška, V., Startienè, G. 1999. Mikroekonomika. [Microeconomics].

Strange, S. 1998. States and Markets. London; New York: Pinter Publishers.

The discussion about Madison comes from Mary Ann Wycoff and Wesley K. Shogan. 1993. "Community Policing in Madison: Quality from the Inside Out," National Institute of Justice Research Report.

Trofimovs, I.; Ivančiks, J. 2017. Psychological aspects of operational and investigative activities as a factor of strengthening of national security, Journal of Security and Sustainability Issues Vol 7 No1, pp. 55-65. https://doi.org/10.9770/jssi.2017.7.1(5)

Tumalavičius, V.; Greičius, S. 2017. Decision Making of the Ensuring Public Security at the Level of the State Territorial Borders, Journal of Security and Sustainability Issues Vol. 7, No1, pp. 27-37. https://doi.org/10.9770/jssi.2017.7.1(3)

Urbonas, J.A.; Maksvytienè, I.; Sabonienè, A. 2009. Ekonomikos teorijos: Ateitis ir dabarties tendencijos. [The theory of economics: the trends of present time and future].

Vaitiekienė, E.; Mesonis, G. 2011. Lyginamoji konstitucinè teisè. [Comparative constitutional right].

Vaitiekienė, E.; Vidrinskaitè, S. 2001. Lietuvos konstitucinės teisès ịvadas. [Introduction to the theory of Lithuanian Constitutional law].

Varian, Hal R. 2003. Intermediate Mikroeconomics. A Modern Approach Sixth Edition. W.W. Norton \& Company, Inc., New York, 2003.

Varian, Hal R. 2004. Mikroekonomika. Šiuolaikinis požiūris. [Microeconomics. Contemporary look]. 
JOURNAL OF SECURITY AND SUSTAINABILITY ISSUES

ISSN 2029-7017 print/ISSN 2029-7025 online

Williamson O.E. 1979. Transactions Cost Economics: The Governance of Contractual Relations. Journal of Law and Economics.

Žilys, J. 2012. Lietuvos Konstitucinè teisè. [Constitutional Law of Lithuania]. 